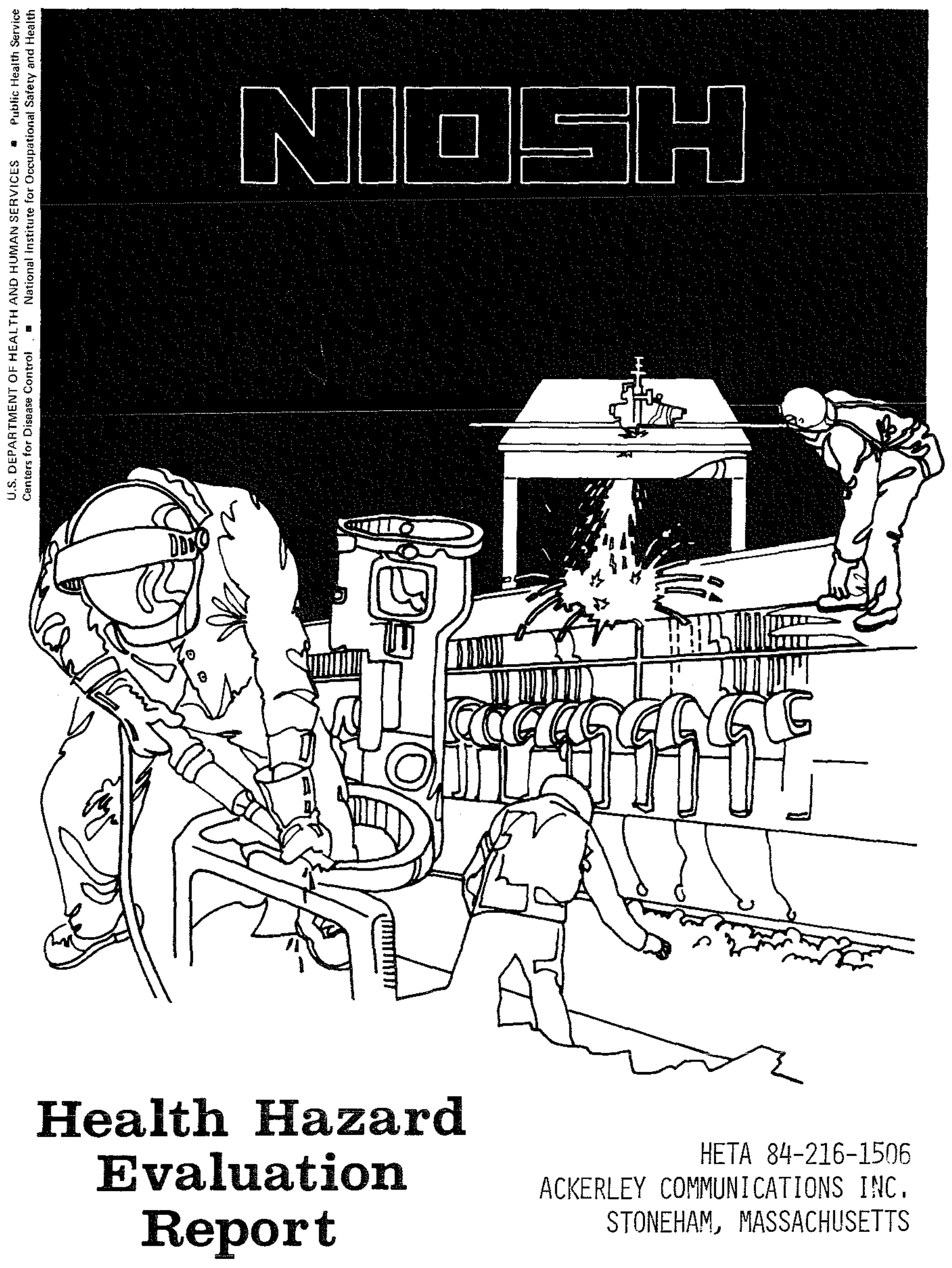


The Hazard Evaluations and Technical Assistance Branch of MIOSH conducts field investigations of possible health hazards in the workplace. These

investigations are conducted under the authority of Section $20(a)(E)$ of the occupational Safety and Health Act of $1970,2 S$ U.S.C. $66 S(a)(6)$ which authorizes the Secretary of Health and Human Services, following a written request from any employer or authorized representative of employees, to determine whether any substance normally found in the place of employment has potentialiy toxic effects in such concentrations as used or found.

The Hazard Evaluations and Technical Assistance Branch also provides, upon request, medical, nursing, and industrial hygiene technical and consultative assistance (TA) to Federal, state, and 10cal agencies; 1abor; industry and other groups or individuals to control occupational health hazards and to prevent related trauma and disease.

Mention of company names or products does not constitute endorsement by the National Institute for Occupational Safety and Health. 
HETA $\varepsilon 4-216-1506$

SEPTEMBER 1984

ACKERLEY COMMUNICATIONS INC,

STOHEHAM, MASSACHLSETTS
KIOSH IMVESTICATOR:

Kevin $P$. McManus, IH

\section{SUMMARY}

In February, 1984 the National Institute for Occupational Safety and Health (NIOSH) received a request to evaluate exposures in the Paint Department at a killboard manufacturing facility, Acker ley

Communications, Stoneham, Massachusetts. Potential contaminants included paints and solvents.

on March 13,1984 a NIOSH industrial hygienist conducted environmentai sampling for organic solvents. Five (5) personal and four (4) areà air samples were collected on activated charcoal. One sample was selected for qualitative analysis by GC/MS, which determined that the solvent mixture resembled mineral spirits. The remaining samples were quantitated for total hydrocarbon content and compared to the criteria established for mineral spirits (naphtha). Sample results ranged from 46 - $77 \mathrm{mg} / \mathrm{m}^{3}$. NIOSH has recommended a standard of $350 \mathrm{mg} / \mathrm{m}^{3}(200 \mathrm{ppm})$ for an 8 to 10-hour workday, 40 hour workweek.

None of the samples exceeded the NIOSH standard for exposure to mineral spirits.

Based on the results of this survey, NIOSH has determined that a health hazard did not exist from exposure to mineral spirits in the paint department. However, due to the nature of the work, employees are cautioned to avoid work practices that could increase exposure.

Keywords: SIC 7312, naphtha, mineral-spirits, paint, advertising, artists. 
II. INTRODUCTION

In February, 1984 the National Institute for Occupational Safety and Health (NIOSH) received a joint request from management and the union at Ackerley Communications of Massachusetts, Inc., Stoneham, Ma. to conduct a Health Hazard Evaluation in the Paint Department. The request was concerned with employees exposure to paints, solvents, and in the early morning hours, carbon monoxide from motor vehicles garaged in the paint department. The most predominant health complaints reported were headaches and Iightheadedness. NIOSH conducted a site visit on March 13, 1984 to sample for organic solvents.

Ackerley Communications manufactures billboards for outdoor advertising. Artists work both indoors and outdoors painting these billboards. Outdoor work is done on location: painting new images over old ones, is done in the field.

\section{EVALUATION METHODS}

Prior to the initial site visit, the practice of garaging motor vehicles in the paint studio was stopped. Therefore this evaluation involved identifying and quantifying employee exposure to paint solvents. As many as twenty employees may be working in the paint department at one time, but on the day of this survey, several were performing work on location. Six employees were active in the paint department on the day of this survey, but only two were to be painting all day.

Five (5) personal and four (4) area air samples were collected on activated charcoal media in the paint department. One sample was selected for qualitative analysis by Gas Chromatography/Mass spectrometry (GC/MS), to identify the organic components of the paint materials. The remaining samples were separated and analyzed according to NIOSH Method P\&CAM 1271.

\section{EVALUATION CRITTERIA}

As a guide to the evaluation of the hazards posed by workplace exposures, NIOSH field staff employ environmental criteria for assessment of a number of chemical and physical agents. These criteria are intended to suggest levels of exposure to which most workers may be exposed up to 10 hours per day, 40 hours per week for a working lifetime without experiencing adverse health effects. It is, however, important to note that not all workers will be protected from adverse health effects if their exposures are maintained below these levels. A small percentage may experience adverse health effects because of individual susceptibility, a pre-existing medical condition, and/or a hypersensitivity (allergy). 
Page - 3 -

In addition, some hazardous substances may act in combination with other workplace exposures, the general environment, or with medications or personal habits of the worker to produce health effects even if the occupational exposures are controlied at the level set by the evaluation criterion. These combined effects are often not considered in the evaluation criteria. Also, some substances are absorbed by direct contact with the skin and mucous membranes, and thus potentially increase the overall exposure. Finally, evaluation criteria may change over the years as new information on the toxic effects of an agent becomes available.

The primary sources of environmental evaluation criteria for the workplace are: 1) NIOSH Criteria Documents and recommendations, 2) the American Conference of Governmental Industrial Hygienists' (ACGIH) Threshold Limit Values (TLV's), and 3) The U.S. Department of Labor (OSHA) occupational health standards. Often, the NIOSH recomnendations and the ACGIH TLV's are lower than the corresponding OSHA standards because they are usually based on more recent information than the OSHA standards. The OSHA standards may also be required to take into account the feasibility of controlling exposures in various industries where the agents are used. The NIOSH-recommended standards, by contrast, are based soley on concerns relating to the prevention of occupati al disease. In evaluating the exposure levels and the recommendations for reducing these levels found in this report, it should be noted that industry is legally required to meet only those levels specified in an OSHA standard.

A time-weighted average (IWA) exposure refers to the average airborne concentration of a substance during a normal 8 to 10-hour workday. Some substances have recommended short term exposure limits or ceiling values which are intended to supplement the IWA where there are recognized toxic effects from high short term exposures.

\section{Naphtha}

Petroleum naphthas or petroleum solvents are complex hydrocarbon mixtures composed mainly of paraffins, mono- and dicycloparaffins, some olefins, alkylbenzenes, naphthenes, and some benzenes, lending the mixture its specific physiochemical properties, such as boiling point range and flash point, etc. These physiochemical characteristics, in turn, determine their specific use, such as rubber solvent, paint thinner, cleaning or degreasing agent, or petroleum refining stock. The specific solvent identified in the air samples at this plant contained 70-80\% C9 to $\mathrm{Cll}$ paraffins (nonane, trimethylhexane, decane, dimethyl octane, undecane), 20-30\% C9 to CII alicyclic

hydrocarbons (cycloparaffins: cyclononane, dimethyl cyclohexane; cyclo-olefins: turpentine, pinene, dicyclopentadiene, etc.), and 5-10\% C7 to C9 aromatic hydroc bons (toluene, xylene, trimethylbenzene, etc.). 
Page - 4 -

Of the major component classes, the paraffins are least toxic;

next are the naphthenes (cycloparaffins). The mixture found in the air most closely resembled mineral spirits, for which NIOSH has recommended a standard of $350 \mathrm{mg} / \mathrm{m} 3(200 \mathrm{ppm})$, for an 8 to 10-hour workday, 40-hour workweek. The OSHA standard for petroleum naphtha is $2000 \mathrm{mg} / \mathrm{m} 3$.

Generally mineral spirits are low irritants to the gastrointestinal tract on ingestion, and to the skin on contact. Systemically, the central nervous system and cardiac systems may be affected. Symptoms include inebriation, followed by headache and nausea. In severe cases, dizziness, convulsions and unconsciousness occasionally result2.

V. RESULTS

The results of the GC/MS analysis of one air sample indicated the presence of mineral spirits (naphtha) with a total hydrocarbon concentration of $60.6 \mathrm{mg} / \mathrm{m} 3$. The ten most prevalent components were $\mathrm{C} 9$ to $\mathrm{Cll}$ alicyclic and branched paraffinic hydrocarbons (70-80\% paraffins, 20-30\% alicyclics). A smaller percentage (5-10\%) of $\mathrm{C} 7$ to $\mathrm{C} 9$ aromatics were also detected.

Using this information, the remainder of the samples were analyzed for total hydrocarbon content and compared to the NIOSH recommended standard for mineral spirits, $350 \mathrm{mg} / \mathrm{m3}$. The following table sumnarizes the results.

$\begin{array}{lllr}\text { Location } & \text { Type } & \text { Time } & \text { Result (mg/m3) } \\ \text { Paint Storage } & \text { Area } & 7: 15-9: 36 & 70.92 \\ & & 9: 36-11: 47 & 76.34 \\ \text { Center Work Bench } & \text { Area } & 7: 15-8: 38 & 54.22 \\ & & 8: 38-11: 53 & 49.26 \\ \text { Center Row Painter } & \text { Personal } & 7: 10-8: 15 & 76.92 \\ & & 8: 15-11: 00 & 60.61 \\ & & 11: 00-12: 00 & 66.67 \\ \text { North Side Painter } & \text { Personal } & 7: 15-8: 11 & 53.57 \\ & & 8: 11-11: 45 & 46.73\end{array}$

VI. CONCLUSION

Based on the results of this survey, NIOSH has determined that a health hazard did not exist from expoure to mineral spirits in the paint department. However due to the nature of the work, employees are cautioned to avoid work practices that could increase exposure. Such practices to be avoided include: leaving open cans of paint in the work area, not turning on the exhaust fans, and careless disposal of painting materials. 
VII. REFERENCES

1. NIOSH Manual of Analytical Methods, 2nd Ed, Volume I, DHEW/NIOSH Pub. No. 77-157-A, April 1977.

2. Occupational Diseases - A Guide to Their Recognition, DHEW/NIOSH Pub. No. 77-181, June 1977.

3. Criteria for a Recommended Standard - Occupational Exposure to Refined Petroleum Solvents, DHEW/NIOSH Pub. No. 77-192

\title{
VIII. ACKNOWIEDGEMENIS
}

Report prepared by:

Kevin P. Malanus

Regional Industrial Hygienist

NIOSH - Region 1

1401 JFK Federal Building

Boston, Massachusetts

Originating office:

\author{
Hazard Evaluations and \\ Technical Assistance Branch \\ Division of Surveillance, \\ Hazard Evaluations and Field \\ Studies \\ Cincinnati, Ohio
}

